\title{
Distribution and Population Density of Rodents and Chigger Mites in Gokseong-gun of Jeollanam-do, Korea
}

Hyeonje Song

Department of Clinical Pathology, Gwangju Health University, Gwangju 62287, Korea

\section{전남 곡성군에서 포획한 들쥐 분포 및 털진드기의 개체군 밀도}

\begin{abstract}
송현제
광주보건대학교 임상병리과

The distribution and population density of rodents and chigger mites were investigated between April 2013 and November 2013 in the Gokseong-gun of Jeollanam-do, Korea. A total of 79 rodents were collected using Sherman collapsible traps, and among them, 73 were Apodemus agrarius (92.4\%), 4 were Crocidura lasiura (5.0\%), and 2 were Microtus fortis (2.5\%). Sixty-eight out of the 79 rodents were parasitized by chiggers, showing an infestation rate of $86.0 \%$ and a chigger index of 74.5; the chigger index of $A$. agrarius was 75.4. From the trapped field rodents, 5,063 chigger mites were collected and identified with 6 species of 2 genera. Leptotrombidium scutellare was the dominant species with 3,535 chiggers (69.8\%), followed by L. pallidum with 777 chiggers (15.3\%). This results showed that the distribution of chigger mites differ in dominant species according to seasons. L. pallidum was the predominant chigger collected in April (34.3\%), May (70.0\%), and June (55.1\%); whereas L. scutellare was the predominant chigger collected in September (75.5\%), October (71.8\%), and November (74.2\%).
\end{abstract}

Key words: Field rodent, Chigger mite, Gokseong-gun

This is an Open Access article distributed under the terms of the Creative Commons Attribution Non-Commercial License (http://creativecommons.org/licenses/by-nc/4.0) which permits unrestricted non-commercial use, distribution, and reproduction in any medium, provided the original work is properly cited

Copyright (c) 2016 The Korean Society for Clinical Laboratory Science. All rights reserved.

\author{
Corresponding author: Hyeonje Song \\ Department of Clinical Pathology, Gwangju \\ Health University, 429 Bukmoonde-ro, \\ Gwangsan-gu, Gwangju 62287, Korea \\ Tel: 82-62-958-7622 \\ Fax: 82-62-953-6085 \\ E-mail: songha1@ghu.ac.kr
}

Received: May 26, 2016

Revised $1^{\text {st: }}$ June 28,2016

Revised $2^{\text {nd }}$ : July 19, 2016

Accepted: July 25, 2016

\section{서 론}

털진드기(Acarina: Trombiculidae)의 유충에 의해 전파되는 Orientia tsutsugamushi는 급성 열성질환인 쯔쯔가무시증 (tsutsugamushi disease)의 원인균이다. 우리나라에서 1951년 참 전 UN군에서 발생 보고가 있은 후 발생보고가 없다가 1986년부터 많은 수의 환자발생이 보고되고 있다[1]. 1957년에 등줄쥐 (Apodemus agrarius)에서 쯔쯔가무시증의 원인체인 O. tsutsugamuship가 분리되어 숙주동물로 밝혀졌으며 또한 등줄쥐에 기생 하는 대잎털진드기(Leptotrombidium pallidum)로 부터 원인균 을 분리하여 우리나라의 매개종이 증명되었다[2]. Ree 등[3]이 대
잎털진드기에서 병원체를 분리하여 쯔쯔가무시증의 매개종임을 재확인 하였으며, 제주도에서 채집된 활순털진드기(L. scutellare) 에서 병원체를 확인하여 우리나라에서 또 다른 매개종임을 보고한 바 있다[4]. PCR방법에 의해 수염털진드기(L. papale), 동양털진 드기(L. orientale), 반도털진드기(L. zetum)가 매개종으로 추가 되 었다[5].

우리나라에서 야생들쥐에 대한 O. tsutsugamushi균의 감염 조 사는 1957년에 등줄쥐, 갈밭쥐(Microtus fortis), 멧밭쥐(Micromys minutus)에서 균이 분리 보고[2]되었고, 그 후 1990년도에 등줄쥐 로 부터 분리 보고가 있었다[6]. 전남지방에서는 nested PCR법으 로 포획한 등줄쥐의 $14.3 \%$ 가 O. tsutsugamushi에 감염된 사실이 
보고된 바 있다[7].

털진드기는 유충기에 사람이나 동물의 조직액을 섭취한 후 자충 으로 탈바꿈한다. 이 때 사람은 우연 숙주가 되며 한번 털진드기의 체내에 O. tsutsugamushi가 감염되면 경란형 수직전파(transovarial transmission)를 하므로 계속 털진드기내에 병원체가 존속되며, 보균된 유충이 조직액을 섭취할 때 병원체가 침입되게 된다[8]. 우 리나라의 털진드기에 대한 분류학적 조사는 1990년 Ree [9]가 총 2과 12속 39종의 털진드기를 확인하여 새로운 검색표를 작성하였 다. 털진드기류의 생태학적 조사는 Lee 등[10]이 경기도 고양군과 강원도 춘천군의 털진드기 기생상을 조사했으며 Ree 등[11]이 중 부 지역을 중심으로 서식처분포 및 숙주동물을 통한 털진드기의 기 생률을 조사하였고, Song 등[12]과 Song [13]에 의해 전라남도에 서 털진드기종에 대한 조사가 보고된 바 있다. 또한 전국 여러 지역 에서 개체군밀도 및 계절별밀도 성향 조사가 이루어졌다 [4,5,14]. 본 연구는 털진드기의 자연숙주로 알려진 들쥐를 포획하고, 들 쥐에 기생하는 털진드기를 조사하여 쯔쯔가무시증을 매개하는 것 으로 확인된 주요 종의 분포를 알아보고자 한다.

\section{재료 및 방법}

\section{1. 조사 기간과 지역}

2013년 4월부터 11월까지 전라남도 곡성군 오곡면 미산리 $\left(35^{\circ} 13^{\prime} 56.2^{\prime \prime} \mathrm{N} 127^{\circ} 18^{\prime} 24.7^{\prime \prime} \mathrm{E}\right)$ 지역을 대상으로 조사하였다.

\section{2. 들쥐 포획}

포획방법은 Sherman collapsible trap $(7.7 \times 9 \times 23 \mathrm{~cm}$; H.B. Sherman, Tallahassee, FL, USA)을 사용하여 살아있는 상태로 들 쥐를 포획하였으며 미끼로는 건빵과 땅콩버터를 사용하였다. 트랩 을 오후3 6시 사이에 들쥐가 서식할 만 한 장소 주변에 $3 \mathrm{~m}$ 정도의 간격으로 설치하였고, 다음날 아침 7 9시에 포획된 쥐틀을 수거 하여 운반용 상자에 넣어 실험실로 이송하였다[8].

\section{3. 털진드기 채집}

실험실로 옮겨진 쥐들은 chloroform (Merck, NJ, USA)으로 흡 입 마취 후 심장에서 직접 채혈하고 Jackson 등[2]의 방법에 따라 쥐의 종을 동정하였다. 그 후 거꾸로 매달아 놓고 그 밑에 물을 약 1 $\mathrm{cm}$ 정도 담은 플라스틱 용기를 2일간 놓아두었다. 24시간마다 플 라스틱 용기를 입체현미경하에서 경검하여 물에 떨어진 털진드기 를 채집하여 $70 \%$ 에틸알콜에 보존하였다. 2 일 후에 쥐의 표피와 털 부위를 입체현미경하 $(\times 20)$ 에서 경검하여 피부에 남아있는 털진 드기도 함께 채집 보존하였다[9].

\section{4. 털진드기의 표본 제작 및 동정}

$70 \%$ 에틸알콜에 보존한 털진드기를 한 마리씩 slide glass위에 올려놓고 그 위에 PVA포매용액(polyvinyle alcohol 56\%, lactic acid 22\%, phenol solution $22 \%$ )을 적당량 떨어뜨린 후 해부용 침 을 사용하여 등쪽을 위로 향하게 하고 cover glass를 씨웠다. Slide glass를 비등점까지 순간 가열하여 털진드기 표본 내부를 투명하게 함과 동시에 다리를 곧게 뻗치도록 하였다[3]. 제작된 털진드기 표 본은 광학현미경(Olympus, Tokyo, Japan)을 이용 100배와 400 배에서Ree [9]의 검색표에 따라 동정 분류하였으며, 분류된 털진드 기는 종류별로 정리하여 기록, 보관하였다. 쥐의 종류별로 쥐 한 마 리에 기생한 털진드기 개체수를 나타내는 chigger index (채집된 털진드기 총 개체수/털진드기를 가지고 있는 들쥐 마리수)를 구하 였다.

\section{결 과}

\section{1. 포획 들쥐의 종류}

Sherman collapsible trap을 이용하여 포획한 들쥐 포획률은 Table 1과 같다. 전체 597개의 trap 중 79마리를 포획하여 포획률 은 $13.2 \%$ 였다. 월별 포획률은 11 월에 $18.0 \%$ 로 가장 높았고 그 다 음으로 10월(17.0\%), 6월(16.0\%) 과 9월(12.1\%)이었으며, 4월과

Table 1. Collection of the field rodents at Gokseong-gun of Jeollanam-do in 2013

\begin{tabular}{lcccccc}
\hline \multirow{2}{*}{ Collecting month } & \multirow{2}{*}{ No. of traps } & Trapping rate (\%) & \multicolumn{5}{c}{ No. of rodents collected } \\
\cline { 5 - 7 } & & & Apodemus agrarius & Crocidura lasiura & Microtus fortis & Total \\
\hline April & 100 & 7.0 & $7 / 7(100)$ & $0 / 7$ & $0 / 7$ & 7 \\
May & 98 & 9.2 & $9 / 9(100)$ & $0 / 9$ & $0 / 9$ & 9 \\
June & 100 & 16.0 & $15 / 16(93.8)$ & $1 / 16(6.25)$ & $0 / 16$ & 16 \\
September & 99 & 12.1 & $11 / 12(91.7)$ & $1 / 12(8.3)$ & $0 / 12$ & 12 \\
October & 100 & 17.0 & $14 / 17(82.4)$ & $2 / 17(11.8)$ & $1 / 17(5.9)$ & 17 \\
November & 100 & 18.0 & $17 / 18(94.4)$ & $0 / 15$ & $1 / 18(5.6)$ & 18 \\
Total (\%) & 597 & 13.2 & $73 / 79(92.4)$ & $4 / 79(5.0)$ & $2 / 79(2.5)$ & 79 \\
\hline
\end{tabular}


5월은 7.0\%와 9.2\%로 낮은 포획률을 보였다. 6회에 걸쳐 포획한 들 쥐 79마리의 종류별 분포는 등줄쥐(A. agrarius)가 73마리로 92.4\%를 차지하여 절대 우점종이었고, 땃쥐(Crocidura lasiura)가 4마리로 5.0\%, 갈밭쥐(M. fortis)가 2마리(2.5\%)였다. 등줄쥐는 4 월에서 11 월까지 채집기간에 대부분을 차지하였고, 땃쥐는 6 월에 서 10 월에 갈밭쥐는 10 월과 11 월에 포획되었다.

\section{2. 털진드기 기생률}

전체 포획한 79마리의 들쥐중 68마리에 털진드기가 기생하고 있어 $86.0 \%$ 의 기생률을 보였고, 5,063 마리의 털진드기가 채집되 어 74.5개체의 chigger index를 보였다. 쥐 종류별로는 73 마리의 채집된 등줄쥐 가운데 67마리에 털진드기가 기생하고 있어 $91.8 \%$ 의 기생률을 보였고, 5,050 마리의 털진드기가 채집되어 chigger index는 75.4개체이었다. 4마리의 땃쥐 중 1마리(25.0\%)에서 13
개체의 진드기가 채집되었고 2 마리의 갈밭쥐에서는 털진드기가 채집되지 않았다. 등줄쥐의 월별 chigger index는 봄철인 4월에 22.3 개체로 증가하였다가 5월과 6월에 10개체 이하로 감소하였 다. 9월(72.6)에 급격하게 증가하여 10월에 172.9개체로 가장 많 았으며 11월에 101.6개체를 보였다. 10월에 포획된 땃쥐에서 유충 이 확인 되었다(Table 2).

\section{3. 털진드기의 종류}

총 5,063 개체의 털진드기의 유충이 채집되었다. Table 3에서 보 는 바와 같이 동정된 2속 6종 가운데 활순털진드기(L. scutellare) 가 3,535개체(69.8\%)로 절대적인 우점종이었고, 다음으로 대잎털 진드기(L. pallidum)가 777 개체(15.3\%)였다. 그밖에 동양털진드 기(L. orientale)가 263개체(5.2\%), 반도털진드기(L. zetum)가 170 개체 (3.4\%) 채집되었다. 수염털진드기(L. papale)와 조선방망

Table 2. The number of chigger mites collected from field rodents by collecting month at Gokseong-gun of Jeollanam-do in 2013

\begin{tabular}{|c|c|c|c|c|c|c|c|c|c|c|c|c|}
\hline \multirow[b]{2}{*}{$\begin{array}{l}\text { Collecting } \\
\text { month }\end{array}$} & \multicolumn{4}{|c|}{ Apodemus agrarius } & \multicolumn{4}{|c|}{ Crocidura lasiura } & \multicolumn{4}{|c|}{ Microtus fortis } \\
\hline & $\begin{array}{l}\text { No. of } \\
\text { rodents } \\
\text { collected }\end{array}$ & $\begin{array}{l}\text { No. of } \\
\text { rodents } \\
\text { with } \\
\text { chiggers }\end{array}$ & $\begin{array}{l}\text { No. of } \\
\text { chiggers } \\
\text { collected }\end{array}$ & $\begin{array}{l}\text { Chigger } \\
\text { index }\end{array}$ & $\begin{array}{l}\text { No. of } \\
\text { rodents } \\
\text { collected }\end{array}$ & $\begin{array}{l}\text { No. of } \\
\text { rodents } \\
\text { with } \\
\text { chiggers }\end{array}$ & $\begin{array}{c}\text { No. of } \\
\text { chiggers } \\
\text { collected }\end{array}$ & $\begin{array}{l}\text { Chigger } \\
\text { index }\end{array}$ & $\begin{array}{l}\text { No. of } \\
\text { rodents } \\
\text { collected }\end{array}$ & $\begin{array}{l}\text { No. of } \\
\text { rodents } \\
\text { with } \\
\text { chiggers }\end{array}$ & $\begin{array}{l}\text { No. of } \\
\text { chiggers } \\
\text { collected }\end{array}$ & $\begin{array}{l}\text { Chigger } \\
\text { index }\end{array}$ \\
\hline April & 7 & 6 & 134 & 22.3 & 0 & 0 & 0 & 0 & 0 & 0 & 0 & 0 \\
\hline May & 9 & 8 & 47 & 5.9 & 0 & 0 & 0 & 0 & 0 & 0 & 0 & 0 \\
\hline June & 15 & 13 & 98 & 7.5 & 1 & 0 & 0 & 0 & 0 & 0 & 0 & 0 \\
\hline September & 11 & 10 & 726 & 72.6 & 1 & 0 & 0 & 0 & 0 & 0 & 0 & 0 \\
\hline October & 14 & 14 & 2,420 & 172.9 & 2 & 1 & 13 & 13.0 & 1 & 0 & 0 & 0 \\
\hline November & 17 & 16 & 1,625 & 101.6 & 0 & 0 & 0 & 0 & 1 & 0 & 0 & 0 \\
\hline Total & 73 & 67 & 5,050 & 75.4 & 4 & 1 & 13 & 13.0 & 2 & 0 & 0 & 0 \\
\hline
\end{tabular}

Table 3. The number of chigger mites by species collected at Gokseong-gun of Jeollanam-do in 2013

\begin{tabular}{|c|c|c|c|c|c|c|c|c|c|}
\hline \multirow{2}{*}{$\begin{array}{l}\text { Collecting } \\
\text { month }\end{array}$} & \multicolumn{8}{|c|}{ No. (\%) of chiggers collected } & \multirow{2}{*}{ Total (\%) } \\
\hline & L. pall & L. scu & L. palp & L. ori & L. zet & E. kors & etc* & $N D^{\star *}$ & \\
\hline April & $\begin{array}{c}46 / 134 \\
(34.3)\end{array}$ & $\begin{array}{c}21 / 134 \\
(15.7)\end{array}$ & $\begin{array}{c}6 / 134 \\
(4.5)\end{array}$ & $\begin{array}{c}33 / 134 \\
(24.6)\end{array}$ & $\begin{array}{c}19 / 134 \\
(14.2)\end{array}$ & $\begin{array}{c}4 / 134 \\
(3.0)\end{array}$ & $\begin{array}{l}0 / 134 \\
(0.0)\end{array}$ & $\begin{array}{c}5 / 134 \\
(3.7)\end{array}$ & $\begin{array}{c}134 / 5,063 \\
(2.6)\end{array}$ \\
\hline May & $\begin{array}{l}31 / 47 \\
(70.0)\end{array}$ & $\begin{array}{l}5 / 47 \\
(10.6)\end{array}$ & $\begin{array}{l}2 / 47 \\
(4.3)\end{array}$ & $\begin{array}{l}7 / 47 \\
(15.0)\end{array}$ & $\begin{array}{l}0 / 47 \\
(0.0)\end{array}$ & $\begin{array}{l}2 / 47 \\
(4.3)\end{array}$ & $\begin{array}{l}0 / 47 \\
(0.0)\end{array}$ & $\begin{array}{l}0 / 47 \\
(0.0)\end{array}$ & $\begin{array}{c}47 / 5,063 \\
(0.9)\end{array}$ \\
\hline June & $\begin{array}{l}54 / 98 \\
(55.1)\end{array}$ & $\begin{array}{l}9 / 98 \\
(9.2)\end{array}$ & $\begin{array}{l}4 / 98 \\
(4.0)\end{array}$ & $\begin{array}{l}5 / 98 \\
(5.1)\end{array}$ & $\begin{array}{l}4 / 98 \\
(4.0)\end{array}$ & $\begin{array}{l}6 / 98 \\
(6.1)\end{array}$ & $\begin{array}{l}3 / 98 \\
(3.0)\end{array}$ & $\begin{array}{l}13 / 98 \\
(13.3)\end{array}$ & $\begin{array}{c}98 / 5,063 \\
(1.9)\end{array}$ \\
\hline September & $\begin{array}{c}87 / 726 \\
(12.0)\end{array}$ & $\begin{array}{c}548 / 726 \\
(75.5)\end{array}$ & $\begin{array}{c}9 / 726 \\
(1.2)\end{array}$ & $\begin{array}{c}27 / 726 \\
(3.7)\end{array}$ & $\begin{array}{c}5 / 726 \\
(0.7)\end{array}$ & $\begin{array}{c}16 / 726 \\
(2.2)\end{array}$ & $\begin{array}{c}0 / 726 \\
(0.0)\end{array}$ & $\begin{array}{c}34 / 726 \\
(4.7)\end{array}$ & $\begin{array}{c}726 / 5,063 \\
(14.3)\end{array}$ \\
\hline October & $\begin{array}{c}378 / 2,433 \\
(15.5)\end{array}$ & $\begin{array}{c}1,746 / 2,433 \\
(71.8)\end{array}$ & $\begin{array}{c}28 / 2,433 \\
(1.2)\end{array}$ & $\begin{array}{c}89 / 2,433 \\
(2.8)\end{array}$ & $\begin{array}{c}69 / 2,433 \\
(3.7)\end{array}$ & $\begin{array}{c}25 / 2,433 \\
(1.0)\end{array}$ & $\begin{array}{c}12 / 2,433 \\
(0.5)\end{array}$ & $\begin{array}{c}86 / 2,433 \\
(3.5)\end{array}$ & $\begin{array}{c}2,433 / 5,063 \\
(48.1)\end{array}$ \\
\hline November & $\begin{array}{c}181 / 1,625 \\
(11.1)\end{array}$ & $\begin{array}{c}1,206 / 1,625 \\
(74.2)\end{array}$ & $\begin{array}{c}24 / 1,625 \\
(1.5)\end{array}$ & $\begin{array}{c}102 / 1,625 \\
(6.3)\end{array}$ & $\begin{array}{c}73 / 1,625 \\
(4.5)\end{array}$ & $\begin{array}{c}18 / 1,625 \\
(1.1)\end{array}$ & $\begin{array}{c}0 / 1,625 \\
(0.0)\end{array}$ & $\begin{array}{c}21 / 1,625 \\
(1.3)\end{array}$ & $\begin{array}{c}1,625 / 5,063 \\
(32.1)\end{array}$ \\
\hline Total (\%) & $\begin{array}{c}777 / 5,063 \\
(15.3)\end{array}$ & $\begin{array}{c}3,535 / 5,063 \\
(69.8)\end{array}$ & $\begin{array}{c}73 / 5,063 \\
(1.4)\end{array}$ & $\begin{array}{c}263 / 5,063 \\
(5.2)\end{array}$ & $\begin{array}{c}170 / 5,063 \\
(3.4)\end{array}$ & $\begin{array}{c}71 / 5,063 \\
(1.4)\end{array}$ & $\begin{array}{c}15 / 5,063 \\
(0.3)\end{array}$ & $\begin{array}{c}159 / 5,063 \\
(3.1)\end{array}$ & $\begin{array}{c}3,120 / 5,063 \\
(100)\end{array}$ \\
\hline
\end{tabular}

*unknown. ${ }^{* *}$ not determined.

Abbreviation: L. pall, Leptotrombidium pallidum; L. scu, L. scutellare; L. palp, L. palpale; L. ori, L. orientale; L. zet, L. zetum; E. kors, Eushoengastia koreaensis. 
이털진드기(Eushoengastia koreaensis)는 73개체와 71개체로 $1.4 \%$ 의 낮은 채집률을 보였다. 대잎털진드기는 봄철인 4 월에 46 개 체(34.3\%), 5월에 31개체(70.0\%), 6월에 54개체(55.1\%)로 높은 발생밀도를 보이다가 가을철인 9월(87개체), 10월(378개체), 11 월(181개체)에는 $11 \sim 16 \%$ 로 적게 분포했다. 활순털진드기는 봄 철인 4월에서 6월까지 $15 \%$ 이하로 낮은 발생밀도를 보이다가, 가 을철인 9월에 548개체(75.5\%), 10월에 1,746개체(71.8\%) 및 11 월에 1,206 개체 $(74.2 \%)$ 로 높은 채집률을 보였다.

\section{고 찰}

쯔쯔가무시증은 O. tsutsugamushi를 가지고 있는 털진드기의 유충에 물렸을 때 감염된다. 자연계에서 털진드기의 생활사는 알, 유충, 자충 및 성충의 4단계 발달과정을 거친다. 알에서 부화된 유 충은 자충으로 탈바꿈하는 과정에서 반드시 동물의 조직액을 필요 로 한다. 수일간의 조직액 섭취가 끝나면 숙주에서 떨어져 지하로 들어가 탈피 후 자충이 된다. O. tsutsugamusht를 가지고 있는 유 충에 물리면 자연숙주나 사람에게 O. tsutsugamushi가 들어가 감 염된다. 유충의 O. tsutsugamushi 감염은 어미로부터 경란형전파 에 의해서 이루어진다[1].

질병관리본부의 감염병 감시연보에 따르면 2013년 우리나라의 쯔쯔가무시증 환자발생은 10,365 명이었고, 월별로는 10 월과 11 월에 9,698명(93.6\%)으로 집중적인 환자발생을 보였다. 또한 전남 지방에서는 1,280 명의 환자가 발생하여 3 명이 사망하였고 곡성군 에서 45명의 환자발생이 있었다[15]. 따라서 쯔쯔가무시증 환자발 생에 대비한 광범위한 역학조사가 요구되는 실정이다. 매개체의 서 식동물을 조사하기 위하여 2013년 4월부터 11월까지 전라남도 곡 성군 오곡면 미산리에서 79마리의 들쥐를 포획하였다. 조사지역에 서 평균 들쥐 포획률은 $13.2 \%$ 로 Lee 등[14]의 $11.8 \%$, Song [13]의 $13.8 \%$ 와 비슷한 포획률을 나타냈다. 그러나 Song 등[12] 과 Ree 등[11]의 $17.4 \%, 22.1 \%$ 보다는 낮아 이는 조사지역과 환경의 차이 및 조사기간의 기후 등에 따른 차이로 생각된다. 등줄쥐가 $92.4 \%$ (73마리)를 차지하여 절대적인 우점종이었으며 땃쥐와 갈밭쥐가 각각 5.0\%, 2.5\%로 적은 수가 포획 되었다. 이는 전라남도가 아닌 다른 조사지역에서도 등줄쥐가 97.6\%[14], 92.8\%[6], 87.0\%[11] 로 우점종이었고, 같은 조사지역인 전라남도에서 등줄쥐가 92.3\%[12]로 우점종이었다는 보고와 같은 결과를 보여 우리나라 에서 들쥐는 등줄쥐가 우점종임을 확인하였다. 계절별로 6월 (16.0\%) 이후에 많이 포획되었고 9월에도 12.1\%를 보여 2009년 조사[14]와 비슷한 추이를 보였으나 9월에 7.8\%[13]보다 많은 포 획률을 보였다. 털진드기 기생률을 보면 등줄쥐의 경우 $91.8 \%$
(67/73)였고 chigger index는 75.4개체였다. Song 등[12]의 보고 에서 등줄쥐가 $73.3 \%$ 의 기생률과 chigger index는 80.4 개체이었 다는 결과와 비교해 보면 본 조사지역에서 털진드기를 갖는 등줄쥐 가 많고 들쥐 한마리가 갖는 털진드기 수는 적은 것으로 나타났다. Chigger index가 Ree 등[11]의 173.7, Lee 등[14]의 135.7보다 적 고 들쥐 포획장소에 따라 털진드기의 분포가 차이가 있다는 보고 [13]가 있어 앞으로 들쥐 채집 장소와 주변의 환경 인자에 대한 조 사가 폭넓게 요구된다.

지금까지의 연구결과를 분석해 보면 대잎털진드기는 북쪽으로 갈수록 개체군 밀도가 높고 남부지방으로 갈수록 밀도가 낮아지는 반면, 활순털진드기는 경기도나 강원도 중부지역에서는 매우 낮은 밀도로 서식하고 남쪽으로 갈수록 개체군 밀도가 높게 나타난 것으 로 보고되었다[10,11,13,14]. 본 조사지역에서도 활순털진드기가 69.8\%로 많은 비율을 차지하여 이러한 보고를 뒷받침하고 있다. 한 편 Lee 등[14]는 전남지방에서 대잎털진드기가 $77.0 \%$ 이고 활순털 진드기가 $19.9 \%$ 로 분포하고, Song 등[12]도 대잎털진드기가 $76.3 \%, 12.9 \%$ 의 활순털진드기가 분포하여 대잎털진드기가 우점 종으로 보고되었는데 본 조사에서는 활순털진드기가 우점종으로 다른 결과를 나타냈다. 이와 같은 결과는 들쥐를 포획하고 털진드 기를 채집하는 장소와 채집하는 시기에 따라 털진드기의 분포가 다 르게 나타난 것으로 생각된다. 본 조사에서도 4월에서 6월까지는 대잎털진드기가 $34.3 \%$ 에서 $70.0 \%$ 까지 높은 밀도로 채집되다가 가을철에는 $16 \%$ 이하로 채집되었고, 활순털진드기는 9월부터 11 월에는 $71.8 \%$ 에서 $75.5 \%$ 로 높은 밀도로 채집되어 채집시기에 따 라 진드기종의 분포가 달라짐을 알 수 있었다.

\section{요 약}

2013년 4월부터 11월까지 전라남도 곡성군 지역을 대상으로 들 쥐를 포획하고 기생하는 털진드기의 분포를 조사하였다. 597 개의 trap에서 79마리를 포획하여 포획률은 $13.2 \%$ 였고, 종류별로는 등 줄쥐가 $92.4 \%$ 를 차지하여 절대 우점종이었다. 79 마리의 들쥐중 68 마리에 털진드기가 기생하고 있어 $86.0 \%$ 의 기생률을 보였고, 74.5개체의 chigger index를 보였다. 5,063개체의 채집한 털진드 기는 2속 6종으로 동정되었고, 활순털진드기가 3,535개체(69.8\%) 로 절대적인 우점종이었다. 계절별로 봄철에는 대잎털진드기, 가 을철에는 활순털진드기가 높은 밀도로 채집되어 진드기종의 분포 가 채집시기에 따라 차이가 있었다. 
Acknowledgements: 이 논문은 2015년도 광주보건대학교 교내

연구비의 지원을 받아 수행된 연구임(No. 3015002).

Funding: None

Conflict of interest: None

\section{References}

1. Chang WH. Current status of tsutsugamushi disease in Korea. J Korean Med Sci. 1995;10:227-238.

2. Jackson EB, Danaska JX, Smadel JE, Fuller HS, Coale MC, Bozeman FM. Occurrence of Rickettsia tustsugamushi in Korea rodents and chiggers. Am J Hyg. 1957;66:309-320.

3. Ree HI, Lee IY, Cho MK. Determination of the vector species of tsutsugamushi disease in Korea. Korean J Parasitol. 1991; 29:87-92.

4. Ree HI, Lee IY, Cho MK. Study on vector mites of tsutsugamushi disease in Cheju Island. Korean J Parasitol. 1992;30:341-348.

5. Ree HI, Kim TE, Lee IY, Jeon SH, Hwang UK, Chang WH. Determination and geographical distribution of Orientia tsutsugamushi serotypes in Korea by nested polymersae chain reaction. Am J Trop Med Hyg. 2001;65:528-534.

6. Ree HI, Lee MC, Lee IY. Study on the population density of chigger mites, the vector of tsutsugamushi disease in Korea. Korean J Zool. 1991;34:257-264.

7. Song HJ, Kee SH, Han HS, Kim KH, Hong SS, Chang WH. Infection rate and serotype distribution of Orientia tsutsuga- mushi among field rodents in Chollanamdo using nested polymerase chain reation. J Korean Soc Microbiol. 1997;32: 301-306.

8. Traub R, Wisseman CL, Jr. The ecology of chigger-borne rickettsiosis (scrub typhus). J Med Entomol. 1974;11:237-303.

9. Ree HI. Fauna and key to the chigger mites of Korea (Acarina: Trombiculidae and Leeuwenhoekiidae). Korean J Syst Zool. 1990;6:57-70.

10. Lee IY, Ree HI, Hong HK. Seasonal prevalence and geographical distribution of trombiculid mites (Acarina: Trombiculidae) in Korea. Korean Zool. 1993;36:408-415.

11. Ree HI, Lee IY, Jeon SH, Yoshida Y. Geographical distribution of vectors and sero-strains of tsutsugamushi disease at mid-south inland of Korea. Korean J Parasitol. 1997;35:171-179.

12. Song HJ, Kim KH, Kim SC, Hong SS, Ree HI. Population density of chigger mites, the vector of tsutsugamushi disease in Chollanam-do, Korea. Korean J Parasitol. 1996;34:27-33.

13. Song HJ. Environmental survey on the vectors and hosts of Tsutsugamushi disease in Jeonnam province, Korea. Korean J Vet Serv. 2012;35:183-189.

14. Lee IY, Kim HC, Lee YS, Seo JH, Lim JW, Yong TS, et al. Geographical distribution and relative abundance of vectors of scrub typhus in the Republic of Korea. Korean J Parasitol. 2009; $47: 381-386$.

15. Korean Center for Disease Control and Prevention. Scrub typhus in Korean [cited 2016 June 15]. Available from: http://www.cdc.go.kr/CDC/info/CdcKrInfo0302.jsp?menuIds= HOME001-MNU1132-MNU1138-MNU0038\&fid=32\&q_type= $\&$ q_value $=\&$ cid $=27068 \&$ pageNum= 